\title{
Southern Jordan Coastal Sediments Quality Assessment at Aqaba Special Economic Zone/Red Sea
}

\author{
Bety Al-Saqarat ${ }^{*}$, Mahmoud Abbas ${ }^{2}$, Taghreed Ma'aytah ${ }^{3}$, Ahmad Al Shdaifat ${ }^{4}$, \\ Wadah Mahmoud ${ }^{5}$ \\ ${ }^{1}$ Department of Geology, University of Jordan, Amman, Jordan \\ ${ }^{2}$ Department of Geology, China University of Geosciences, Wuhan, China \\ ${ }^{3}$ Aqaba Special Economic Zone Authority, Aqaba, Jordan \\ ${ }^{4}$ Water, Environment and Energy Center, University of Jordan, Amman, Jordan \\ ${ }^{5}$ Department of Geology, University of Jordan, Amman, Jordan \\ Email: ^b.saqarat@ju.edu.jo, subariny_m2008@yahoo.com,tmaaytah@aseza.jo,ahmad87geo@gmail.com, \\ w.mahmoud@ju.edu.jo
}

How to cite this paper: Al-Saqarat, B., Abbas, M., Ma'aytah, T., Al Shdaifat, A. and Mahmoud, W. (2017) Southern Jordan Coastal Sediments Quality Assessment at Aqaba Special Economic Zone/Red Sea. Journal of Water Resource and Protection, 9, 52-64.

http://dx.doi.org/10.4236/jwarp.2017.91005

Received: November 23, 2016

Accepted: January 13, 2017

Published: January 16, 2017

Copyright $\odot 2017$ by authors and Scientific Research Publishing Inc. This work is licensed under the Creative Commons Attribution International License (CC BY 4.0).

http://creativecommons.org/licenses/by/4.0/

(c) (i) Open Access

\begin{abstract}
The bottom surface sediments at the southern part of the Jordanian coast of the Gulf of Aqaba have been studied. Samples were collected from $10 \mathrm{~m}$ depth at nine coastal stations which are located within two main zones: Marine Park Zone and Industrial Zone. Sedimentation rate, grain size oxygenation state, Loss on Ignition, hydrogen sulfide, calcium carbonate, total phosphorous, organic carbon, organic nitrogen, and heavy metals were analyzed to assess and evaluate the quality of bottom surface sediments. The sedimentation rate at the southern part of the Gulf has been affected by Khamassin winds from the south as a result of sand storm events in southern Jordan and adjacent regions. Floods and streams also played a vital role as a transportation agent of the sediments from the interstitial nearby areas to the Gulf. Also construction works played a minor role. Bottom surface sediments at the different sites were quite different in some chemical properties. Sediments from all stations other than the MSS were fine, gray-black and oxygen deficient. Sediments from the MSS and VC are whitish, better oxygenated and have higher calcium carbonate content since they are typically coral reef sediments coral reef sediments. Coral reef carbonate sediments are well known to have high organic nitrogen concentration as compared to silicate sediments, even those in close proximity. The concentration of phosphorous and calcium carbonate is attributed in the phosphate port to the phosphate by the generation of the dust and coral reef. Whilst, heavy metal concentration due to presence of major sources of metal pollution and intensive human activities. These include ship
\end{abstract}


boat activities, domestic sewage discharges and phosphate rock particles from the phosphate port.

\section{Keywords}

Gulf of Aqaba, Bottom Surface Sediments, Sedimentation Rate, Heavy Metals, Coral Reefs

\section{Introduction}

The near shore marine ecosystem is a dynamic environment that has highly variable bottom sediment types, diverse biological habitats, and localized depositional and transport processes. It is impacted by many activities, such as fishing, recreation, housing, sewage and waste disposal, shipping, and preservation. In many cases, especially adjacent to major metropolitan and agricultural areas, the sediments are polluted and the ecosystem has suffered detrimental effects. An understanding of the mobility, transport rates, paths, and sinks of sedimentary particles and associated contaminants are necessary for predicting both the fate of substances that have been introduced into the ocean and any risk associated with their presence [1] [2].

Bottom sediments of the marine ecosystem play an important role as a natural trap for diverse substances (including contaminants), natural regulatory of the processes that occur inside the seafloor and also constitute a source of nutrients for the water columns above them [3] [4]. The type of sediments is the main factor recognizing the oxygenation state of the bottom and interstitial waters, which controls the trophic structure [5] [6] [7] [8].

Many authors have worked with sediments of the Red Sea, including those in the Gulf of Aqaba [7]-[28]. These studies focused on the texture, mineralogy, geochemistry, sedimentation rate, chemical composition and heavy metal content, ion transport in reef sediments and skeletal debris diversity and distribution.

The bottom sediments of the Gulf of Aqaba are loose, unconsolidated materials originating from marine living organisms (reefs, calcareous algae, fragmented solid biogenic material, skeletal remains) or from offshore land (fragmented rocks or fecal materials) which are transported to the gulf through wind, water runoff or floods [29].

Coral reef sediments are generally loose and unconsolidated in nature. They are generated mainly from reef rock, calcareous algae, fragmented solid biogenic material, calcium carbonate skeletal remains such as foraminifers' tests and mollusk shells, beach rock fragments, fecal material produced by organisms which ingest sediments and terrigenous material driven from the surrounding land by winds or runoff.

This manuscript aims to study and evaluate the quality of coastal surface sediments of the Gulf of Aqaba in the southern Jordanian coast, and identifies its 
physiochemical characteristics by different means.

\section{Study Area}

The Gulf of Aqaba, located in southern Jordan representing the northern extension of the Red Sea, is a part of the Syrian-African rift system extending up to $6000 \mathrm{Km}$. The Gulf itself is about $180 \mathrm{Km}$ long and $15-25 \mathrm{Km}$ wide and its floor is up to $1850 \mathrm{~m}$ deep [30]. The Jordanian coast of the Gulf of Aqaba is relatively small and extends for about $27 \mathrm{~km}$ along the northern eastern part of the Gulf. It represents the only marine access of Jordan where much of the sea related activities are focused. About 30\% of the coastline is used for port activities and $7 \mathrm{~km}$ of the Jordanian coast have been declared as marine protected area (About 25\% of the total coast area).

The Gulf of Aqaba lies in an arid climatic zone, i.e. mild in winter and hot in summer. In the summer months, typically lasting 6 months, the average temperature ranges between 30.6 and $32.1^{\circ} \mathrm{C}$ and mean annual evaporation about 1.6 $1.8 \mathrm{~m}$. Coastal summer maximums can be over $40^{\circ} \mathrm{C}$, while daily temperature in winter can drop to $10^{\circ} \mathrm{C}$. The mean annual participation is about $32 \mathrm{~mm}$ on the coast and $50-100 \mathrm{~mm}$ inland which all fall between October and April [31]. The relative humidity at the shoreline of the Gulf ranges between 30 - 55\%.

The prevailing wind direction in the Gulf is northern in origin (North, North East and North West) with daily average values ranging between $1.0 \mathrm{~m} / \mathrm{s}$ and 6.2 $\mathrm{m} / \mathrm{s}$, and an overall average of $3.7 \mathrm{~m} / \mathrm{s}$, in early and late summer months Khamasin winds are initiated from the South as a result of sand storm events in southern Jordan and adjacent regions [32].

\section{Materials and Methods}

Bottom surface sediment samples have been collected by scuba divers at $10 \mathrm{~m}$ depth in nine coastal sites within the two main zones: the Marine Park Zone and Industrial Zone. The Marine Park Zone includes six stations which are: Marine Science Station (MSS), Coral Club (MP1), National Camp (MP2), Visitor Center (VC), AlSodasiat (MP3), and Tala Bay inside (TBI). On the other hand, the Industrial Zone includes three stations and they are: Hararyah (HAR), Industrial Complex (IC) and Camera (CAM), as illustrated in Figure 1(A) and Figure 1(B), while Figure $1(C)$ shows an aerial view of the study area [33].

Sampling was confined to the upper $5 \mathrm{~cm}$ of the sediment layers. Upon returning to the lab, samples were rinsed with distilled water and dried to a constant weight at $60^{\circ} \mathrm{C}$ in a well-ventilated oven. Samples were collected in duplicates from each station once a year. Sedimentation rate was measured using glass sediment traps with depth to neck opening diameter ratio of 3:1, deployed vertically $1 \mathrm{~m}$ above sea bottom using metallic stands. The traps were retrieved and their contents dried and weighed monthly

Organic carbon and grain size analysis were undertaken according to the methods described by Holm and Mcntyre (1971) [34]. Total phosphorus and organic nitrogen were measured as reactive phosphorus and ammonia, following 


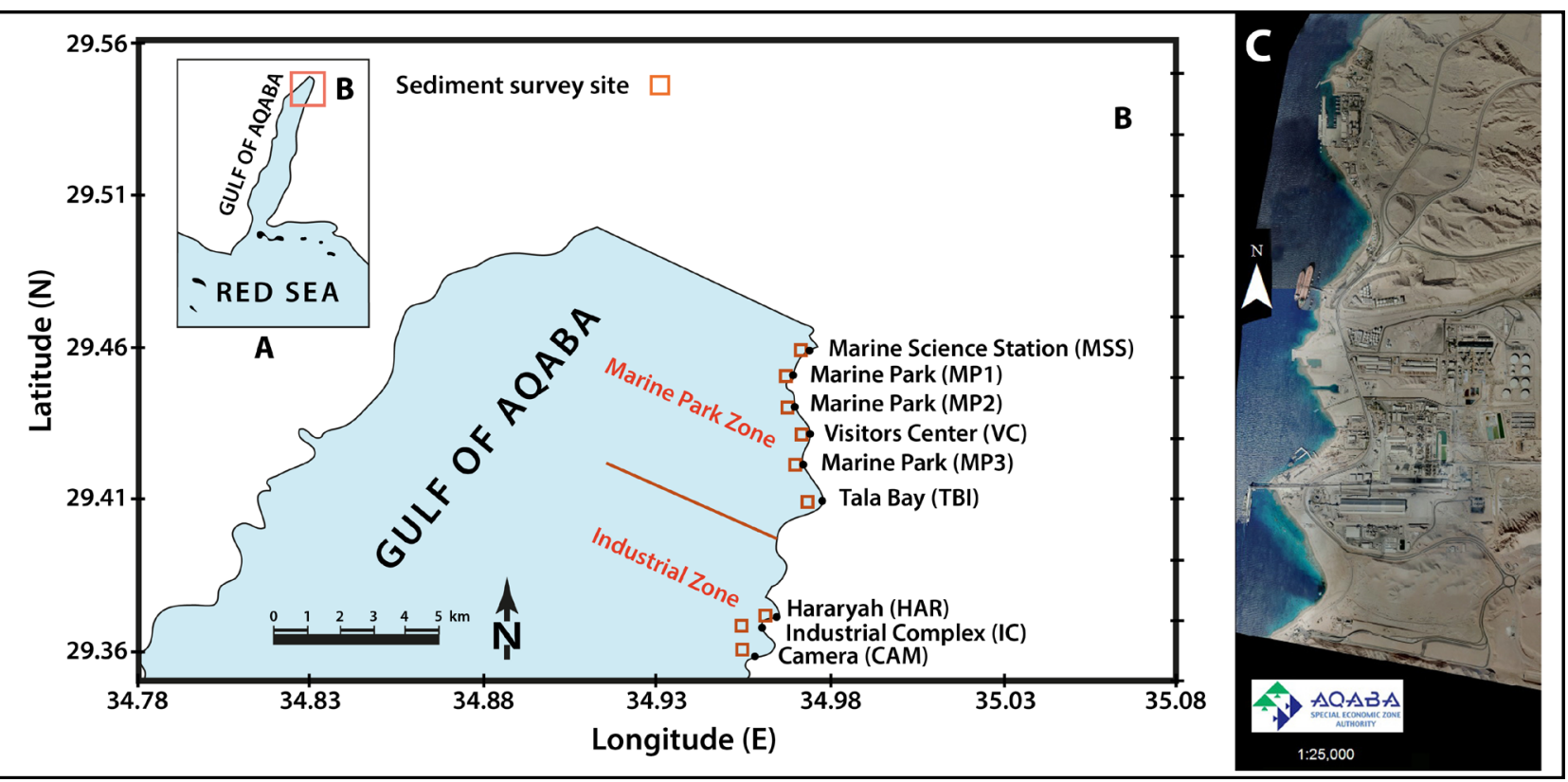

Figure 1. (A) Index map showing the Gulf of Aqaba; (B) map showing the locations of sediment surveys; (C) aerial view of the study area (ASEZA open files, 2015) [33].

the ignition method and Kjeldhal digestion, respectively. All analytical methods have been tested and verified in research. All analyses were carried out in duplicates. Heavy elements including Chromium $(\mathrm{Cr})$, Lead $(\mathrm{Pb})$, Copper $(\mathrm{Cu})$, Cadmium (Cd), and Zinc ( $\mathrm{Zn})$ were analyzed in sediment samples from all stations. Heavy metals were measured by using atomic absorption spectrophotometry, following nitric-perochloric acid digestion, according to the method described by Abu Hilal [26].

\section{Results and Discussion}

\subsection{Sedimentation Rate in the Coastal Habitat}

Available data from 2012 from the most important sites along the southern Jordanian coast were chosen for sedimentation rate monitoring. These monitoring sites include: the Marine Park Zone (MPZ), Tala bay Inside (TBI), and the Industrial Zone (IZ).

The sedimentation rates are mostly similar in 2012 for MPZ and IZ sites with a notable increase in TBI with the average value $3.13 \mathrm{mg} \cdot \mathrm{cm}^{-2} \cdot$ day $^{-1}$. The yearly average value for all site is lowest among the four recorded years (2012-2015) about $1.326 \mathrm{mg} \cdot \mathrm{cm}^{-2} \cdot \mathrm{day}^{-1}$. In 2013 the average value for all stations is the highest to reach around $2.066 \mathrm{mg} \cdot \mathrm{cm}^{-2} \cdot \mathrm{day}^{-1}$. The abnormally high values were recorded at MBZ and TBI with the average value up to 1.96 and $3.57 \mathrm{mg} \cdot \mathrm{cm}^{-2} \cdot \mathrm{day}^{-1}$ respectively, as listed in Table 1.

Relatively high annual average of sedimentation rate were observed at MPZ station in 2014 and 2015 in comparison with 2012 and 2013 of around 1.526 and $2.44 \mathrm{mg} \cdot \mathrm{cm}^{-2} \cdot$ day $^{-1}$ respectively, whilst, TBI and IZ stations showed a constant values. The difference, however, was not substantial, Figure 2. 
Table 1. Annual average summary of the sedimentation rate $\left(\mathrm{mg} \cdot \mathrm{cm}^{-2} \cdot \mathrm{d}^{-1}\right)$ at stations along the southern Jordanian coast of the Gulf of Aqaba during the periods 2012-2015.

\begin{tabular}{|c|c|c|c|c|}
\hline Station & 2012 & 2013 & 2014 & 2015 \\
\hline $\begin{array}{l}\text { Marine Park Zone } \\
\text { (MPZ) }\end{array}$ & $\begin{array}{c}0.2 \\
\mathrm{mg} \cdot \mathrm{cm}^{-2} \cdot \mathrm{day}^{-1}\end{array}$ & $\begin{array}{c}1.96 \\
\mathrm{mg} \cdot \mathrm{cm}^{-2} \cdot \mathrm{day}^{-1}\end{array}$ & $\begin{array}{c}1.04 \\
\mathrm{mg} \cdot \mathrm{cm}^{-2} \cdot \text { day }^{-1}\end{array}$ & $\begin{array}{c}2.44 \\
\mathrm{mg} \cdot \mathrm{cm}^{-2} \cdot \mathrm{day}^{-1}\end{array}$ \\
\hline $\begin{array}{l}\text { Tala Bay Inside } \\
\text { (TBI) }\end{array}$ & $\begin{array}{c}3.13 \\
\mathrm{mg} \cdot \mathrm{cm}^{-2} \cdot \text { day }^{-1}\end{array}$ & $\begin{array}{c}3.57 \\
\mathrm{mg} \cdot \mathrm{cm}^{-2} \cdot \mathrm{day}^{-1}\end{array}$ & $\begin{array}{c}2.47 \\
\mathrm{mg} \cdot \mathrm{cm}^{-2} \cdot \mathrm{day}^{-1}\end{array}$ & $\begin{array}{c}3.01 \\
\mathrm{mg} \cdot \mathrm{cm}^{-2} \cdot \mathrm{day}^{-1}\end{array}$ \\
\hline $\begin{array}{l}\text { Industrial Zone } \\
\text { (IZ) }\end{array}$ & $\begin{array}{c}0.60 \\
\mathrm{mg} \cdot \mathrm{cm}^{-2} \cdot \mathrm{day}^{-1}\end{array}$ & $\begin{array}{c}0.65 \\
\mathrm{mg} \cdot \mathrm{cm}^{-2} \cdot \mathrm{day}^{-1}\end{array}$ & $\begin{array}{c}1.07 \\
\mathrm{mg} \cdot \mathrm{cm}^{-2} \cdot \text { day }^{-1}\end{array}$ & $\begin{array}{c}0.66 \\
\mathrm{mg} \cdot \mathrm{cm}^{-2} \cdot \mathrm{day}^{-1}\end{array}$ \\
\hline $\begin{array}{c}\text { Average of } \\
\text { sedimentation rate per year }\end{array}$ & $\begin{array}{c}1.326 \\
\mathrm{mg} \cdot \mathrm{cm}^{-2} \cdot \mathrm{day}^{-1}\end{array}$ & $\begin{array}{c}2.066 \\
\mathrm{mg} \cdot \mathrm{cm}^{-2} \cdot \mathrm{day}^{-1}\end{array}$ & $\begin{array}{c}1.526 \\
\mathrm{mg} \cdot \mathrm{cm}^{-2} \cdot \mathrm{day}^{-1}\end{array}$ & $\begin{array}{c}2.44 \\
\mathrm{mg} \cdot \mathrm{cm}^{-2} \cdot \mathrm{day}^{-1}\end{array}$ \\
\hline
\end{tabular}

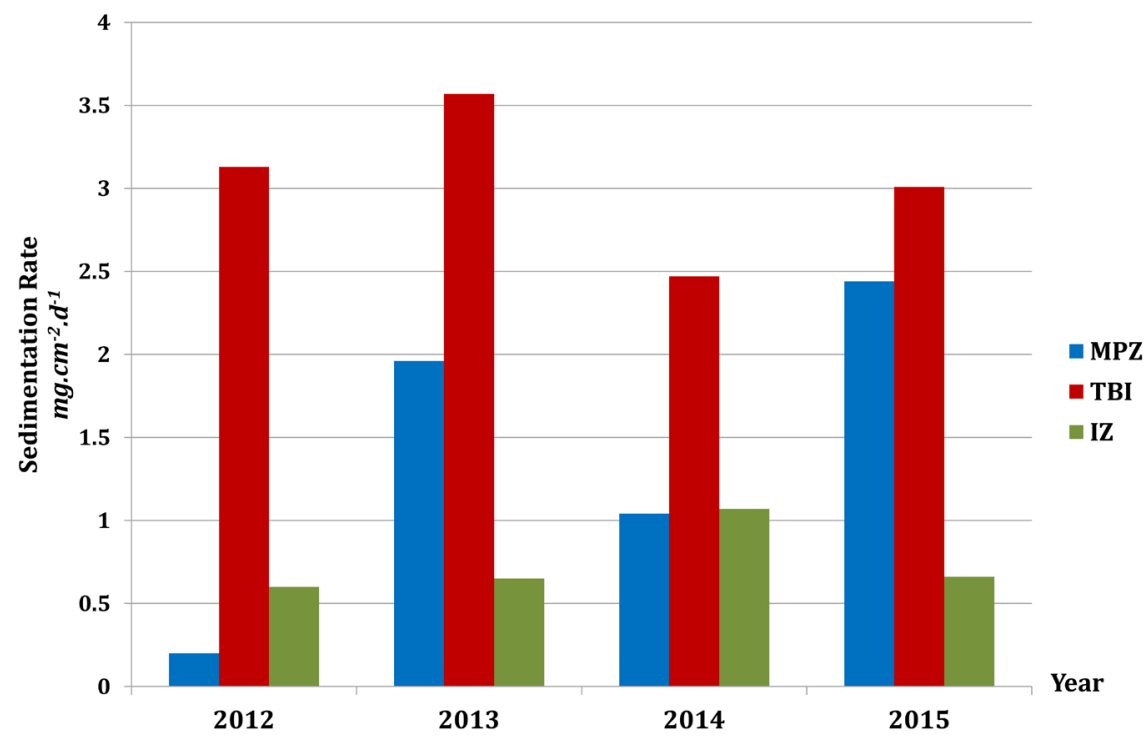

Figure 2. The annual average of the sedimentation rate $\left(\mathrm{mg} \cdot \mathrm{cm}^{-2} \cdot \mathrm{d}^{-1}\right)$ at the coastal stations along the southern Jordanian coast of the Gulf of Aqaba during the period 2012-2015.

The outcrops of southern Aqaba area comprised of Quaternary sediments deposited near the shoreline of the Gulf Aqaba. These sediments consist of red sandstone, Aqaba formation which consists of clays, sandstone, and conglomerate, uplifted fossil coral reefs and alluvium sediments and wadi sediments [35] [36] [37].

These outcrops are located at the north-eastern mountains of the southern Jordanian coast of the Gulf; forming wadis and steep slopes. The bottom sediments of the Gulf and sedimentation rate are, undoubtly, influenced by the surface nearby sediments and originated from these sediments by wind, runoff and floods.

Total sedimentation rate at all sites showed similar values with average $2.07 \pm$ $1.07 \mathrm{mg} \cdot \mathrm{cm}^{-2} \cdot$ day $^{-1}$. Higher values were recorded at Talabay inside (TBI) during some of the sampling events, which could be attributed to the nature of the substratum in the area. However, the lowest value was recorded at the IZ site. 


\subsection{Physicochemical Characteristics of Coastal Bottom Sediments}

\subsubsection{Color, Odor and Redox-Potential}

Color and odor provide important information about the oxygenation state of the bottom sediments reflecting the biological productivity and the trophic structure. These, however, are subjective characteristics given in most cases descriptively. This study gives a weight to the sediment color that enables us to treat this characteristic objectively, especially for long term comparisons. Sediment natural color, either white or brown, is given a weight of zero. Natural to gray color is given $(-0.5)$, gray to natural $(-0.75)$, gray color is given $(-1)$, gray to black is given $(-1.5)$, black to gray $(-1.75)$ and black is given $(-2)$. The negative sign refers to poorer oxygenation.

There is an appropriate association between the two variables Figure 3. All sediment samples exhibited negative values, reflecting high oxygen consumption. The VC sampling site, which had white (natural) sediments, exhibited the lowest redox potential values (+94 and -90 , respectively) indicating the best oxygenated sediments.

Bottom surface sediments at the different sites were quite different in some chemical properties. Sediments from all stations other than the MSS were fine, gray-black and oxygen deficient. Sediments from the MSS and VC are whitish, better oxygenated and had higher calcium carbonate content. This is typical in coral reef sediments. Coral reef carbonate sediments are well known to have high organic nitrogen concentration as compared to silicate sediments, even those in close neighborhood [7].

\subsubsection{Loss on Ignition (LOI)}

Loss on ignition has been carried out to understand the temporal and spatial changes of particulate organic carbon for understanding the course of the decomposition processes in coastal marine sediments and to estimate the sediment properties such as water content, organic matter, inorganic carbon and mineralogenic residue [38] [39] [40].

The results of Ignition loss were obtained from nine sites along the southern coastline of the Gulf of Aqaba during 2015 Figure 4(a) Mean values for all sitesranged between 1.80 - $12.7 \mathrm{~g} \cdot \mathrm{kg}^{-1}$. TBI, HAR, IC, and CAM sites exhibited rela-

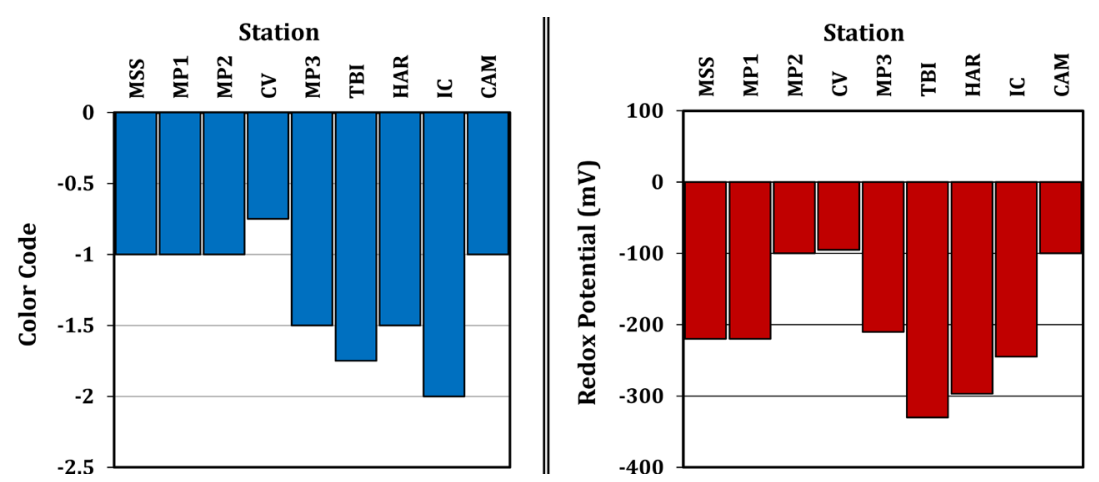

Figure 3. Color code (left) and redox potential (mV) (right), of bottom surface sediment from nine stations along the Jordanian coast of the Gulf of Aqaba. 


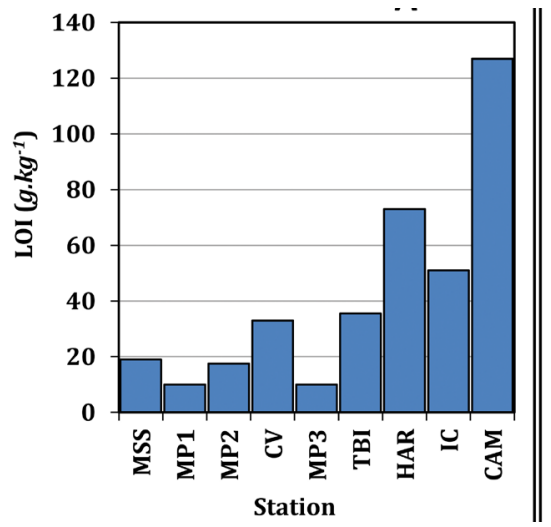

(a)

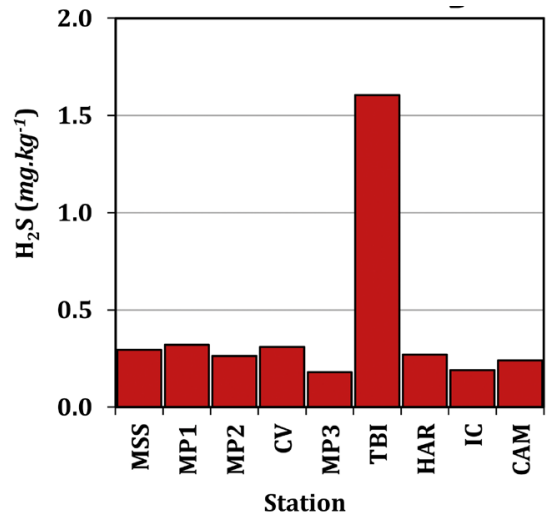

(b)

Figure 4. (a) Loss on ignition $\left(\mathrm{g} \cdot \mathrm{kg}^{-1}\right)$ and (b) hydrogen sulfide concentration of bottom surface sediment from nine stations along the southern Jordanian coast of the Gulf of Aqaba during the year 2015.

tively higher values than other stations. However, ignition loss values here need to be interpreted with care. Coral reef calcium carbonate sediment tends to lose weight upon ignition due to carbonate partial decomposition and conversion to calcium oxide and lost as carbon dioxide. Sulfur also is an easily oxidizable metal by heat and if present will result in false high organic content.

\subsubsection{Hydrogen Sulfide $\left(\mathrm{H}_{2} \mathrm{~S}\right)$}

Hydrogen sulfide concentration $\left(\mathrm{mg} \cdot \mathrm{kg}^{-1}\right)$ is shown in Figure $4(\mathrm{~b})$. The Mean sulfide values were relatively low, ranging between $0.07-0.04 \mathrm{mg} \cdot \mathrm{kg}^{-1}$ at all sites, except for TBI which recorded a relatively high concentration of $\mathrm{H}_{2} \mathrm{~S}$ around 1.7 $\mathrm{mg} \cdot \mathrm{kg}^{-1}$. The differences in hydrogen sulfide values between the sites tend to reflect the oxygenation state of the bottom sediments.

High organic nitrogen concentrations in coral reef sediments most likely result from deposition and sinking of living material [8]. Poor oxygenation associated with the black-gray color of the sediments at the stations TBI does not necessarily mean poor environmental conditions. In fact the bottom habitat in some of these stations is sea grass beds which are well known to extract oxygen for their metabolism from the surrounding sediments.

\subsubsection{Grain Size}

Bottom surface sediment grain size distribution in the coastal stations during the year 2015 is shown in Figure 5. Differences between the different sediment types were minor. Bottom surface sediments at all stations possess almost similar textural compositions. The most dominant fractions were collected in the medium sand $(250-500,180-250$, and $125-180 \mu \mathrm{m})$ which comprises about $64 \%$ of all sizes (range $41 \%$ - 91\%). However, abnormally, very fine sediments $(77 \%<63$ $\mu \mathrm{m})$ were collected from CAM site during 2015.

\subsubsection{Calcium Carbonate, Total Phosphorus, Organic Carbon and Organic Nitrogen}

Concentrations of calcium carbonate, total phosphorus, organic carbon and or- 
ganic nitrogen in bottom surface sediment during 2015 are shown in Figure 6. It is obvious that the calcium carbonate concentration in the surface bottom sediment at the MSS and VC is high (more than 45\%). The other stations had considerably lower calcium carbonate concentration ranging between $2 \%-28 \%$, reflecting the nature of the bottom habitat. Some stations are typical coral reef sites; while, others are a deposition environment in the case of the Phosphate Port and non-coralline sea grass bottom habitat.

Total phosphorus Figure 6, was significantly higher in the surface bottom sediments at the Industrial Complex (IC) than elsewhere $\left(1.9 \mathrm{~g} \cdot \mathrm{kg}^{-1}\right.$ compared to average of $\left.1.04 \mathrm{~g} \cdot \mathrm{kg}^{-1}\right)$. At the other sites, total phosphorus is relatively equal. The lowest value of total phosphorus is at the Marine Science Station (MSS) around $0.3 \mathrm{~g} \cdot \mathrm{kg}^{-1}$. The solubility of powdered phosphate rock in seawater is an open question. Based on preliminary laboratory experiments and records of soluble phosphate concentrations in seawater in the framework of the present program, it can be safely stated that under the normal conditions of Aqaba seawater ( $\mathrm{pH} \sim 8.4$ and salinity $\sim 40.5 \mathrm{psu}$ ) solubility of the Jordanian phosphate rock does not have any considerable significance.

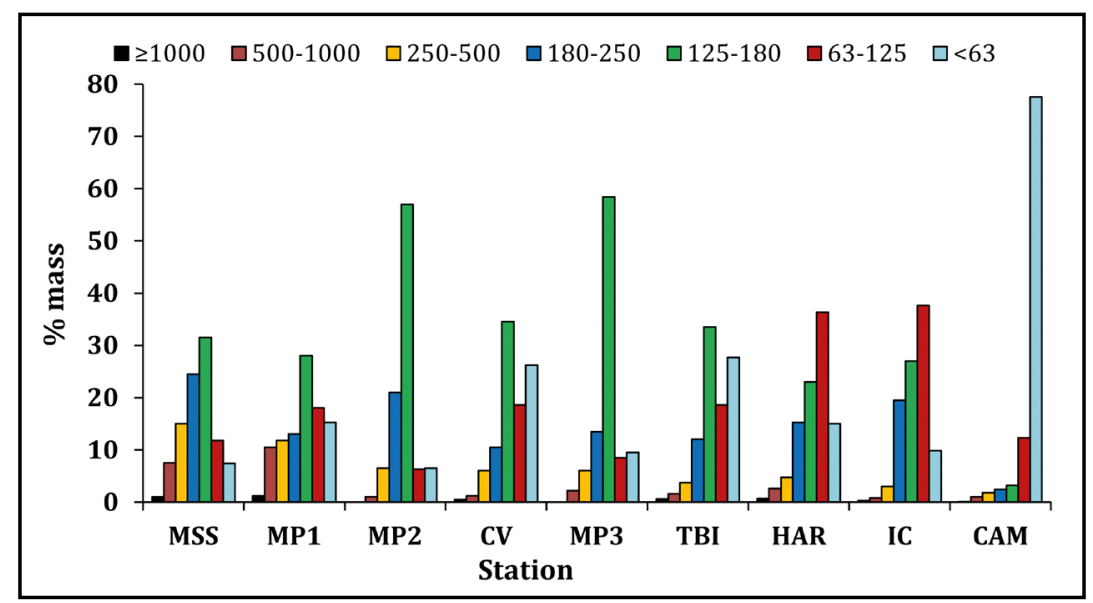

Figure 5. Grain size distribution at nine coastal sites along the Jordanian coast of the Gulf of Aqaba during the year 2015.

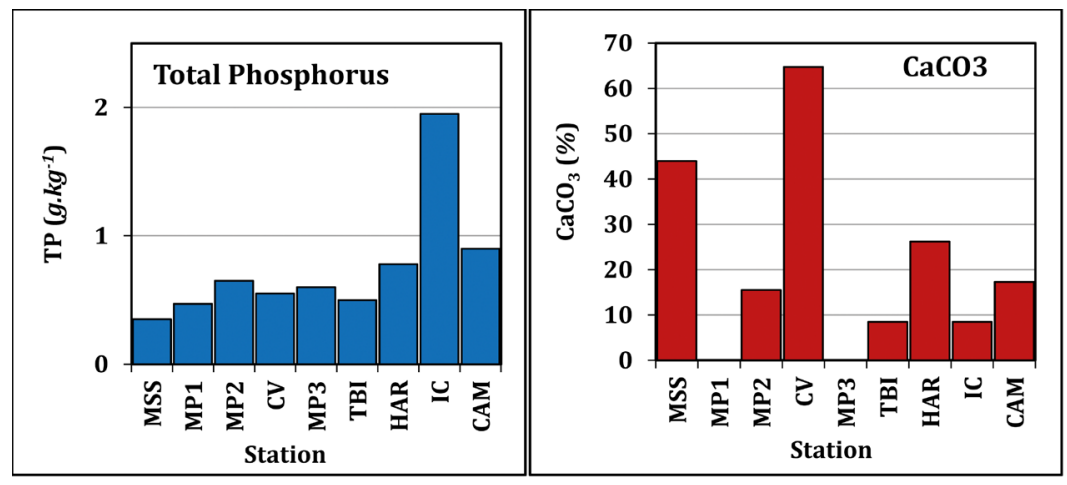

Figure 6. Records of total phosphorus $\left(\mathrm{g} \cdot \mathrm{kg}^{-1}\right.$ ) and calcium carbonate (wt\%) of bottom surface sediment at sixteen stations along the Jordanian coast of the Gulf of Aqaba during 2015. 
With respect to organic carbon Figure 7, all stations exhibited concentrations during the year 2015 ranging between 0.54 to $2.92 \mathrm{~g} \cdot \mathrm{kg}^{-1}$. HAR and CAM exhibited higher organic carbon concentration than the other stations. Organic nitrogen concentrations (Figure 8) which refer here to Kjeldahl digestion ranged from 0.73 to $1.84 \mathrm{~g} \cdot \mathrm{kg}^{-1}$. The HAR site exhibited the highest value and IC had the lowest one.

\subsubsection{Heavy Metals}

Heavy metal concentrations in the marine environment can be monitored in sediment water and biota [41]. Sediment may help in identifying industrially affected areas and the use of sediment cores may provide a historical record of the heavy metal burden. However, metal concentration records are strongly affected by the analytical method. The concentration depends on many physical and chemical factors, such as the sedimentation rate and organic carbon content. Besides, metal concentrations in sediments do not represent the metals bioavailability.
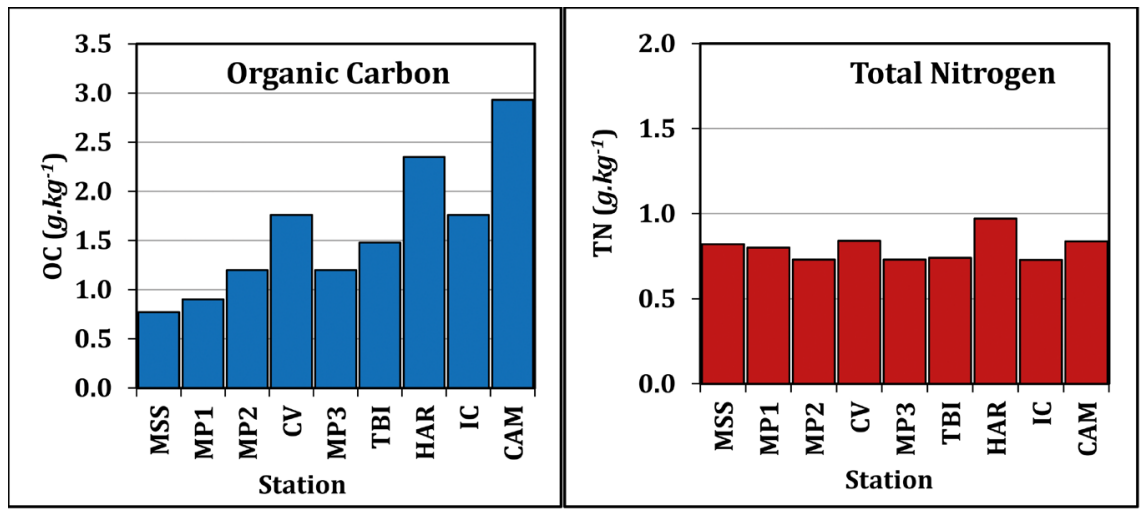

Figure 7. Records of organic carbon $\left(\mathrm{g} \cdot \mathrm{kg}^{-1}\right)$ and organic nitrogen $\left(\mathrm{g} \cdot \mathrm{kg}^{-1}\right)$ of bottom surface sediment from the southern Jordanian coast of the Gulf of Aqaba during 2015.

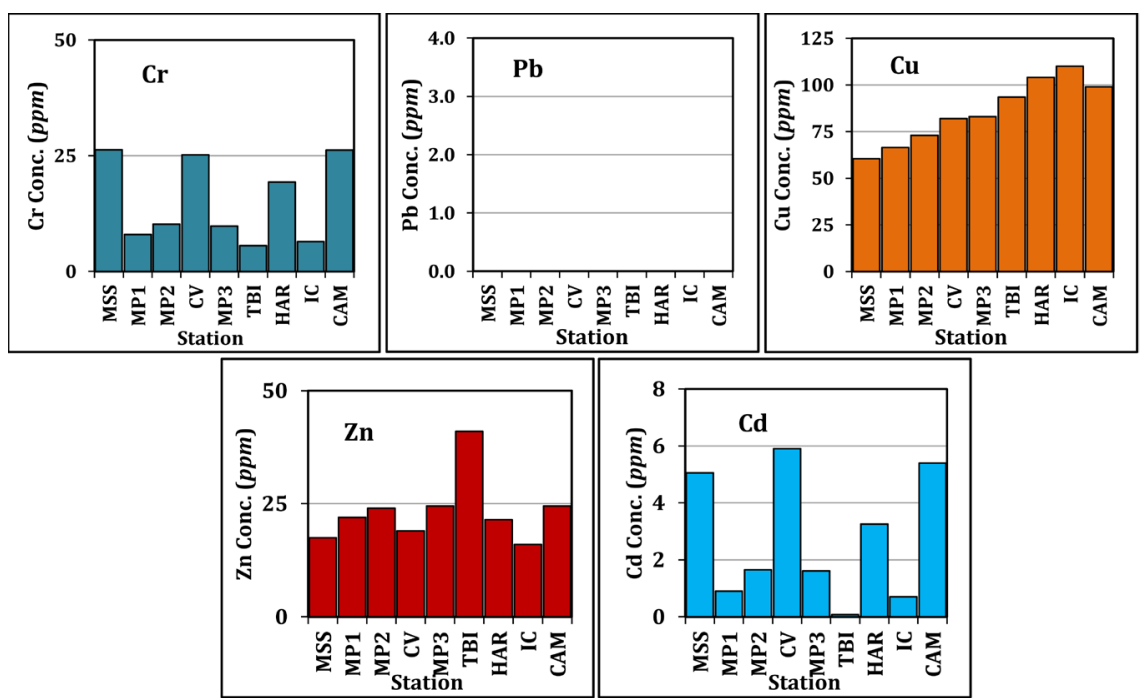

Figure 8. Heavy metal concentrations ( $\mathrm{ppm}$ ) of bottom surface sediments from the southern Jordanian coast of the Gulf of Aqaba during 2015. 
Analysis of the heavy metals; cadmium, chromium, copper, lead and zinc $\left(\mathrm{mg} \cdot \mathrm{kg}^{-1}\right)$, in bottom surface sediments was carried out from 2009; the results for 2015 are shown in Figure 8. Concentrations of lead and cadmium were generally low. Concentrations of chromium, copper and zinc relative to the other metals were generally high. The mean values recorded from all stations were 19, 85, and $25 \mathrm{ppm}$ for $\mathrm{Cr}, \mathrm{Cu}$, and $\mathrm{Zn}$, respectively. However, values for Copper were abnormally high at all stations which could indicate a pollution source for these metals Figure 8.

\section{Conclusions}

The bottom surface sediments of the Gulf of Aqaba provide crucial data about the ecosystem state of the Gulf, due to their large storage capacity of organic matter. They are the main factor determining the oxygenation state of the bottom and interstitial waters, which in turn controls the trophic structure. The sedimentation rate at the southern part of the Gulf had been affected by Khamasin winds, which blows from the South as a result of sand storm events in southern Jordan and adjacent regions. Floods and streams also play a vital role as a transportation agent of sediments from the interstitial nearby areas to the Gulf. Also, in the TBI site it is affected by construction.

Dissolved reactive phosphate concentrations in the overlaying water were also reported to be significantly higher. Today's records show slightly higher sedimentation rates with no significant elevation in the dissolved reactive phosphate concentration as a result of wise management actions. The phosphate loading process has also been improved substantially by the use of chalk feeders and better training and the enhancing of environmental awareness of operators. This is probably the main reason for the decrease in sedimentation rate.

Coral reef supported the high concentration of calcium carbonate at the MSS site which is from a biological origin. Calcium carbonate shows a general distribution pattern parallel to that of phosphorus, which can be correlated and suggests a common important source of these elements. The phosphate port is close to the MSS site in its northern side, the percentage of phosphate at the phosphate port is at its highest along the Jordanian coastal part of the Gulf of Aqaba where a thick phosphate dust layer covers the original sediments. The dust layer can be transported by the current direction that is the dominant current direction at the southern part of Aqaba is south-southwestward.

The recognition of heavy metals in marine sediments, water and organisms is essential to identifying their environmental pollution, since these metals can be toxic even if they are present in trace amounts [42]. Earlier studies showed that short time variability in minor and trace constituents of bottom surface sediments, which counteract the persistence of regular patterns, is not uncommon. This is due to patchiness, instantaneous inputs especially in ports and industrial sites, rapid biogeochemical recycling and current and wave disturbances. Nevertheless heavy metals concentrations in the study sites were comparable to average concentrations recorded previously at different sites along the Jordanian 
coast [27]. The relatively high levels of heavy metals and Organic Carbon in the bottom surface sediments are mainly to be due to the presence of major sources of metal pollution and intensive human activities. These include shipping activities, domestic sewage discharges and phosphate rock particles from the phosphate port.

\section{Acknowledgements}

The authors are so thankful for Aqaba Special Economic Zone Authority for the generous cooperation and analysis done for this study. Special thanks for Prof. Dr. Omar Rimawi and Prof. Dr. Ghaleb Jarrar for their extensive suggestion and reviewing.

\section{References}

[1] Strickland, J.D.H. and Parsons, T.R. (1972) A Practical Handbook of Seawater Analysis. Fisheries Res. Board of Canada, Ottawa, 310 p.

[2] Berner, R.A. (1982) Burial of Organic Carbon and Pyrite Sulfur in the Modern Ocean: Its Geochemical and Environmental Significance. American Journal of Science, 282, 451-473. https://doi.org/10.2475/ajs.282.4.451

[3] Al Moghrabi, S. and Khaymi-Horani, H. (1997) Follow up on the Distribution of Coliform Bacteria along the Jordanian Coastline of the Gulf of Aqaba. Mu'tah Lil Buhuth wad Dirasat.

[4] Baudo, R., Beltrami, M. and Rossi, D. (1999) In Situ Tests to Assess the Potential Toxicity of Aquatic Sediments. Aquatic Ecosystem Health and Management, 2, 361-365. https://doi.org/10.1016/S1463-4988(99)00013-5

[5] Wollast, R. (1991) The Coastal Organic Carbon Cycle: Fluxes, Sources, and Sinks,. Ocean Margin Processes in Global Change, Dahlem Workshop Report, 365-381.

[6] Murphy, T.P., Lawson, A., Kumagai, M. and Babin, J. (1999) Review of Emerging Issues in Sediment Treatment. Aquatic Ecosystem Health and Management, 2, 419-434.

[7] Al-Rousan, S. (1998) Sediment Role in Nutrient Cycle within Coral Reefs of the Gulf of Aqaba, Red Sea. Master Thesis, Yarmouk University, Irbid.

[8] Al-Rousan, S., Rasheed, M. and Badran, M. (2004) Nutrient Diffusive Fluxes from Sediments in the Northern Gulf of Aqaba, Red Sea. Scientia Marina, 68, 483-490. https://doi.org/10.3989/scimar.2004.68n4483

[9] Shukri, N. and Higazy, R. (1944) Mechanical Analysis of Some Bottom Deposits of the Northern Red Sea. Journal of Sedimentary Petrology, 14, 70-85.

https://doi.org/10.2110/jsr.14.70

[10] Mohamed, A. (1949) The Distribution of Organic Matter in Sediments from the Northern Red Sea. American Journal of Science, 247, 116-127.

https://doi.org/10.2475/ajs.247.2.116

[11] Maxwell, W. (1968) Atlas of the Great Barrier Reef. Elsevier, Amsterdam.

[12] Friedman, G. (1968) Geology and Geochemistry of Reefs, Carbonate Sediments, and Waters, Gulf of Aqaba (Elat), Red Sea. Journal of Sedimentary Petrology, 38, 895-919.

[13] Stoddart, D. (1969) Ecology and Morphology of Recent Coral Reefs. Biological Reviews of the Cambridge Philosophical Society, 44, 433-498.

https://doi.org/10.1111/j.1469-185X.1969.tb00609.x 
[14] Milliman, J. (1974) Marine Carbonates. Springer, New York.

[15] Wahbeh, M.I. (1976) Temporal and Spatial Distribution of the Intertidal Sand Beach Hippa-Mesodesma Community in the Jordan Gulf of Aqaba. Master Thesis, University of Jordan, Amman.

[16] Freemantle, M., Hulings, N., Mulqi, M. and Watton, E. (1978) Calcium and Phosphate in the Jordan Gulf of Aqaba. Marine Pollution, 9, 79-80. https://doi.org/10.1016/0025-326X(78)90454-X

[17] Hulings, N. and Ismail, N. (1978) The Organic Carbon Content of Seagrass, Coraline and Terrigenous Sand Bottoms in the Jordanian Gulf of Aqaba. Dirasat, 5, 155-162.

[18] Reiss, Z. and Hottngers, L. (1984) The Gulf of Aqaba: Ecological Micropaleontolgy. Springer, Berlin, 55-66. https://doi.org/10.1007/978-3-642-69787-6

[19] Ayalon, A. Bar-Matthews, M. and Nathan, Y. (1981) Geochemistry of Stream Sediments along the Western Coast of the Gulf of Elat (Aqaba). Journal of Geochemical Exploration, 15, 393-404. https://doi.org/10.1016/0375-6742(81)90075-3

[20] Vaugelas, J. and Naim, O. (1982) Organic Matter Distribution in the Marine Sediments of the Jordanian Gulf of Aqaba. Proceeding of the 4th International Coral Reef Symposium, 1, 651-656.

[21] Ismail, N. and Awad, J. (1984) Organic Carbon and Calcium Carbonate Distribution near Sewage Outfalls in the Jordan Gulf of Aqaba. Red Sea. Arab Gulf Journal of Scientific Research, 2, 547-558.

[22] Reiss, Z., Luz, B., Almogi-Labin, A., Halicz, E., Winter, A., Wolf, M. and Ross, D. (1980) Late Quaternary Paleoceanography of the Gulf of Aqaba (Elat), Red Sea. Quaternary Research, 14, 294-308. https://doi.org/10.1016/0033-5894(80)90013-7

[23] Friedman, G. (1985) Gulf of Elat (Aqaba), Geological and Sedimentological Framework.

[24] Abu-Hilal, A. (1985) Phosphate Pollution in the Jordan Gulf of Aqaba. Marine Pollution, 16, 281-285. https://doi.org/10.1016/0025-326X(85)90567-3

[25] Abu-Hilal, A. (1986) Fluoride Distribution in the Jordan Gulf of Aqaba (Red Sea). Science of the Total Environment, 49, 227-234. https://doi.org/10.1016/0048-9697(86)90242-1

[26] Abu-Hilal, A. (1987) Distribution of Trace Elements in near Shore Surface Sediments from the Jordan Gulf of Aqaba. Marine Pollution, 18, 190-193. https://doi.org/10.1016/0025-326X(87)90245-1

[27] Abu-Hilal, A.H. and Badran, M.I. (1991) Effect of Pollution Sources on Metal Concentration in Sediment Cores from the Gulf of Aqaba (Red Sea). Marine Pollution, 21, 190-197. https://doi.org/10.1016/0025-326X(90)90501-X

[28] Al-Fukaha, F. (1994) A Textural and Geochemical Study on Reef Sediments of the Gulf of Aqaba, and the Input of Airborne Dust to the Area. MSc Thesis, Yarmouk University, Aqaba.

[29] Hulings, N.C. (1989) A Review of Marine Research in the Gulf of Aqaba. Marine Science Station, Aqaba, 267 p.

[30] Ben Avraham, Z., Almagor, G. and Garfunkel, Z. (1979) Sediments and Structure of the Gulf of Elat (Aqaba)-Northern Red Sea. Sedimentary Geology, 23, 239-267. https://doi.org/10.1016/0037-0738(79)90016-2

[31] Freiwan, M. and Kadioglu, M., (2008) Climate Variability in Jordan. International Journal of Climatology, 28, 69-89. https://doi.org/10.1002/joc.1512

[32] Saqqa, W. and Atallah, M. (2004) Characterization of the Aeolian Terrain Facies in 
Wadi Araba Desert, Southwestern Jordan. Geomorphology, 62, 63-87. https://doi.org/10.1016/j.geomorph.2004.02.002

[33] ASEZA (2015) Aqaba Special Economic Zone Authority. Aqaba.

[34] Holme, N. and Mcintyre, A. (1971) Methods of the Study of Marine Benthos. IBP Handbook 16.

[35] Abdelhamid, G., Ibrahim, K. and Mortimer, C. (1990) The Geology of Ayn Al Hashim, Jabal Al Mubarak and Al Yamaniyya. Map Sheets No. 3048I, 3048IV and 2948I, NRA, Amman, Bull No. 27.

[36] Ibrahim, K. and Abedlhamid, G. (1991) AL Yamaniyya Clay Deposits. Int. Rep., NRA, Amman.

[37] Abbas, M., Al-Saqarat, B. and Al-Shdaifat, A. (2016) Paleoclimate Reconstruction of the Quaternary Sediments near the Gulf of Aqaba (Southern Jordan). Arabian Journal of Geoscience, 9, 361. https://doi.org/10.1007/s12517-016-2346-5

[38] Kristensen, E. and Blackburne, T. (1987) The Fate of Organic Carbon and Nitrogen in Experimental Marine Sediment Systems: Influence of Bioturbation and Anoxia. Journal of Marine Research, 45, 231-257. https://doi.org/10.1357/002224087788400927

[39] Dean, W.E. (1974) Determination of Carbonate and Organic Matter in Calcareous Sediments and Sedimentary Rocks by Loss on Ignition: Comparison with Other Methods. Journal of Sedimentary Petrology, 44, 242-248.

[40] Maher, L.J. (1998) Automating the Dreary Measurements for Loss on Ignition. INQUA Sub-Commission on Data-Handling Methods, Newsletter 18.

[41] Badran, M.I. (1998) Shells of Nerita Gastropode, Bio-Monitors of Heavy Metal Pollution around the Indian Ocean. Proceedings of the International Symposium on Marine Pollution, Monaco, 5-9 October 1998, 31-37.

[42] Cosma, B., Drago, M., Piccazo, M., Scarponi, G. and Tucci, S. (1979) Heavy Metals in Ligurian Sea Sediments: Distribution of $\mathrm{Cr}, \mathrm{Cu}, \mathrm{Ni}$, and $\mathrm{Mn}$ in Superficial Sediments. Marine Chemistry, 8, 125-142.

https://doi.org/10.1016/0304-4203(79)90011-2

\section{Submit or recommend next manuscript to SCIRP and we will provide best service for you:}

Accepting pre-submission inquiries through Email, Facebook, LinkedIn, Twitter, etc. A wide selection of journals (inclusive of 9 subjects, more than 200 journals)

Providing 24-hour high-quality service

User-friendly online submission system

Fair and swift peer-review system

Efficient typesetting and proofreading procedure

Display of the result of downloads and visits, as well as the number of cited articles

Maximum dissemination of your research work

Submit your manuscript at: http://papersubmission.scirp.org/

Or contact jwarp@scirp.org 